\title{
The Knowledge Based Society - Myth or Reality for Romania?
}

\author{
Simona Nicolae \\ Politehnica University of Bucharest, Bucharest, Romania
}

\begin{abstract}
As at microeconomic level the human capital is one of the most important assets of any company and the only one that can undermine its future development from within, as well the human capital regarded as stock and flow of knowledge can cause the regress or, contrary, the progress of a nation. The access of human resource to education and information technology is the most important way that can turn it into human capital, this being so, later, to become part of the foundation of the knowledge-based society. The proposed paper aims to investigate which is the Romania's position in front of the challenges raised by the knowledge-based society and in what stage of its efforts it is in its way towards a knowledge - based society. Is it the right or the wrong way? Is it a myth or a reality? The last part of the paper brings in the prime plan several recommendations designed to draw some action directions for those responsible for decision making at macro and micro economic in this area, decisions that in the author's opinion should be focused rather on efficiency, quality and strategy than on quantity, bureaucracy and immediate interest.
\end{abstract}

Keywords: Human capital, Knowledge-Based Society, education, ICTs

\section{Introduction}

The knowledge, inventiveness and work efforts of people, together with our ability to continuously develop, produce and sell new goods and services, are keys to exploiting the opportunities presented by globalization and technological development. Globalization and technological development present a number of significant challenges. A wellqualified labor force is crucial to ensuring competitiveness and prosperity. This means that the demands on the general and vocational skills of the labor force will grow, while demand for low-skilled labor will decline in the years to come.

Continued growth in the economy is also dependent on increasing the labor force. Everyone is needed in the labor market.
This includes those who currently have difficulty keeping a foothold in the labor market. Besides, in Romania, the labor force is aging, and the new entrants into the labor market are fewer than the expected exits.

According to the National Institute of Statistics and Economic Studies (NISES 1, 2008) the adult population has experienced a slight numerical increase until around the years 2006-2007, after which it starts to fall slightly until 2010, more moderate in the period 2010-2020 and then more and more pronounced until 2050. Population aged 1565 years may reach 9.4 million persons in 2050, with 5.6 million persons less than in 2007. Thus, the share of labor in the total population will reach $58.5 \%$ in 2050 . Across the country the total demographic

Copyright (C) 2010 C Simona Nicolae. This is an open access article distributed under the Creative Commons Attribution License unported 3.0, which permits unrestricted use, distribution, and reproduction in any medium, provided that original work is properly cited.

Author contact: Simona Nicolae, e-mail: nsim2005@yahoo.com 
dependency will increase from 43 (2007) to 71 young and elderly people per 100 adults (2050). Also, in the period 2007-2050 the population with age corresponding to compulsory education (7-14 years) will be

As a consequence, the skills of the labor force must therefore be increased at all levels. More people must have a qualifying education, and more people need to go through the education system faster and pass out into the labor market. Moreover, there is need for a significant increase in the adult education and continuing training, not least in order to raise the level of those with the lowest level of education and training.

More than ever, perhaps, the focus should be on the quality and flexibility of human resources, as long as, in quantitative terms, the human resources have not recorded an increase.

The two issues which I will present in the paper will emphasize the most important ways to arrive at a knowledge - based society. Access to education and access to information technology are the pillars of the basis of any knowledge-based society. The quality of education that transforms information into knowledge is essential. Also, the political will purposed to direct resources to increase the quality of education becomes absolutely necessary when we are talking about the knowledgebased society.

The paper is intended to be a starting point of this analysis and aims to show to what extent is provided the basis for a future building of the Knowledge-Based Society in Romania.

\section{The access to education}

Chen and Dahlam (2004) mentioned that a well-educated and skilled population is essential to the efficient creation, acquisition, dissemination and utilization of relevant knowledge, which tends to increase total factor productivity and hence economic growth. Basic education is necessary to increase peoples' capacity to learn and to use information. On the other hand, technical secondary-level education, and higher education in engineering and scientific areas is necessary for technological innovation. reduced by $48.5 \%$. The same trend $(-59.1 \%)$ are registered for age group 15-24 years, who could continue the process of education in high schools, vocational schools, colleges and universities.

To emphasize the access to education of the human resources in Romania we'll stop at a set of basic indicators that reflects their participation in education and the internal efficiency of the Romanian educational system.

Table 1: The Participation in education and the internal efficiency of the educational system

\begin{tabular}{|c|c|}
\hline Overall & $\begin{array}{l}\text { Primary and } \\
\text { Secondary Education }\end{array}$ \\
\hline $\begin{array}{l}\text { 1. The enrolment } \\
\text { rate of school age } \\
\text { population } \\
\text { 2. The average } \\
\text { period of } \\
\text { attendance } \\
\text { education } \\
\text { 3. School life } \\
\text { expectancy }\end{array}$ & $\begin{array}{l}\text { 1. The enrolment rate } \\
\text { of school age } \\
\text { population in primary } \\
\text { and secondary } \\
\text { education. } \\
2 \text {. The average period } \\
\text { of attendance the } \\
\text { primary and secondary } \\
\text { education } \\
\text { 3. The rate of early } \\
\text { school leaving } \\
4 \text {. The school dropout } \\
\text { rate }\end{array}$ \\
\hline $\begin{array}{l}\text { High-school and } \\
\text { vocational } \\
\text { education }\end{array}$ & $\begin{array}{l}\text { Post high-school } \\
\text { education, non- } \\
\text { tertiary/tertiary } \\
\text { education }\end{array}$ \\
\hline $\begin{array}{l}\text { 1. The enrolment } \\
\text { rate of school age } \\
\text { population in } \\
\text { high-school and } \\
\text { vocational } \\
\text { education } \\
\text { 2. The average } \\
\text { period of } \\
\text { attendance the } \\
\text { high-school and } \\
\text { vocational } \\
\text { education } \\
\text { 3. The rate of } \\
\text { transition in high- } \\
\text { school/ vocational } \\
\text { education } \\
\text { 4. The school } \\
\text { dropout rate }\end{array}$ & $\begin{array}{l}\text { 1. The enrolment rate } \\
\text { of school age } \\
\text { population in post } \\
\text { secondary education, } \\
\text { non-tertiary/tertiary } \\
2 \text {. Share of students } \\
\text { enrolled in } \\
\text { mathematics, science } \\
\text { and technology } \\
\text { 3. The rate of transition } \\
\text { in higher education } \\
\text { 4. The rate of access to } \\
\text { higher education }\end{array}$ \\
\hline
\end{tabular}




\subsection{Overall}

A. The enrolment rate of school age population in all school levels of education (ISCED 1-6)

The enrolment rate of school age population in all school levels of education (ISCED 1-6) shows a continuous upward trend during the reference period (2000-
2007), the difference between the first and last year being 10 percentage points.

According to the Report on the state of the national system of education, (EDU, 2008), in the academic year 2007/2008 the indicator reaches its maximum value 76.6\%. Comparisons with European countries reveal that, in the year 2006, Romania was situated in the penultimate place.

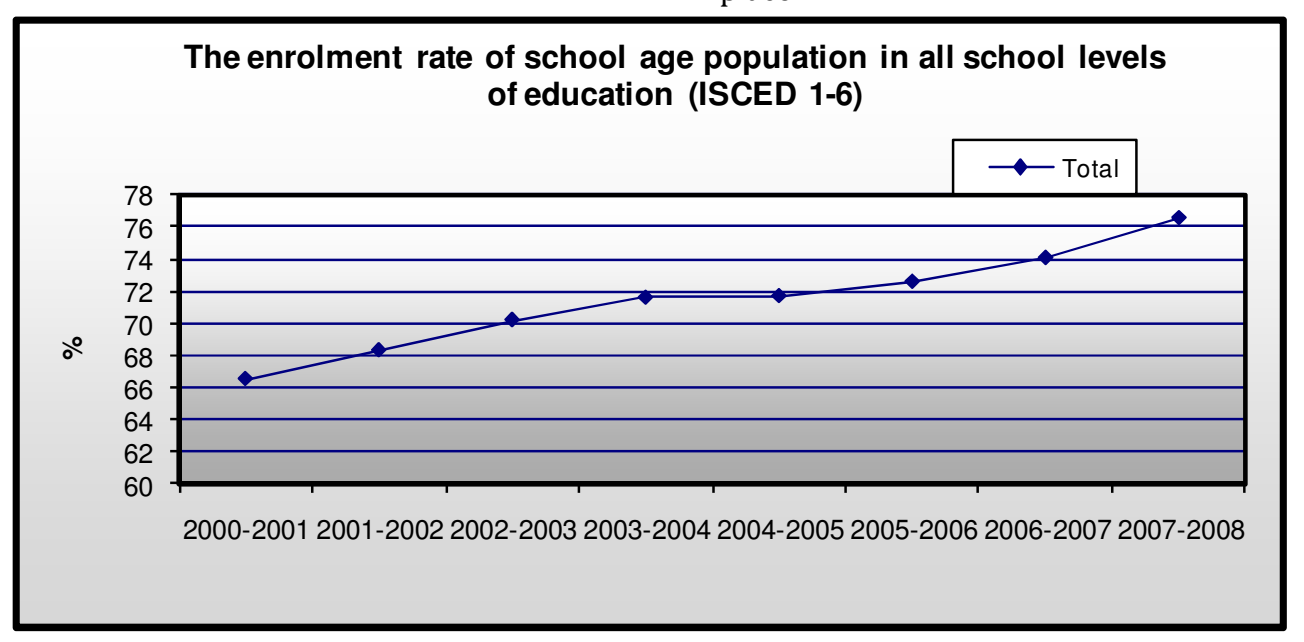

Fig.1 The enrolment rate of school age population in all school levels

\section{B. The average period of attendance education}

The average period of attendance education has increased by 1.7 years during 2000-2007 and 0.3 years in 2007 compared with 2006, reaching 16.3 years. However, Romania continues to be on a lower place compared with other European countries in terms of life school expectancy.

\subsection{Primary and Secondary Education}

\section{A. The enrolment rate of school age population in primary and secondary education.}

The enrolment rate of school age population in primary and secondary education has been $99.2 \%$ in the school year 2007/2008, with approximately 1 pp less compared with the previous school year.

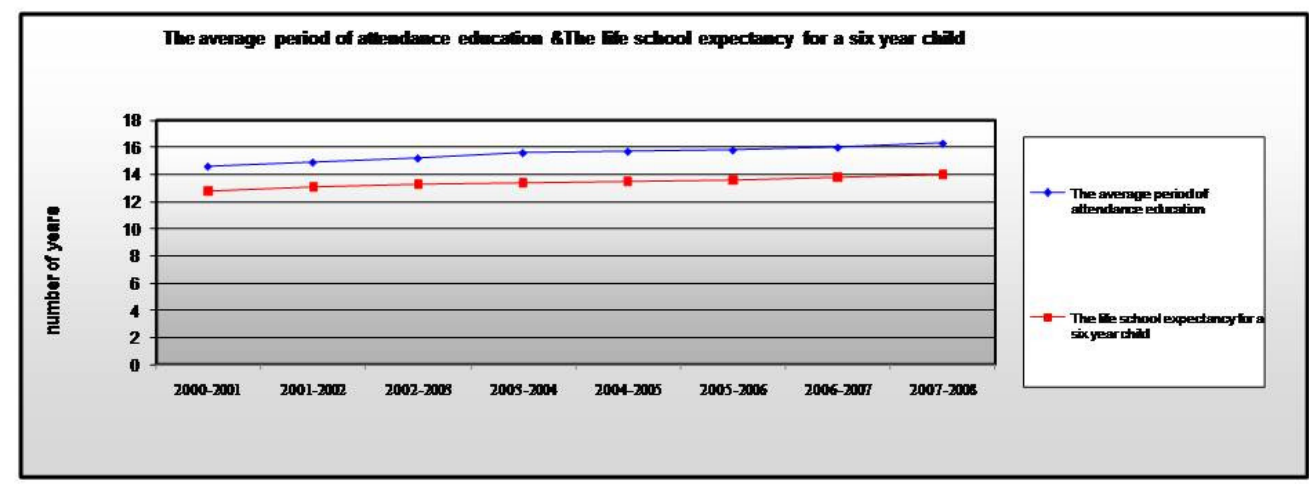

Fig.2. The average period of attendance education \& The life school expectancy for a six year child 
In the primary education, in the last school years, we can seen a decline in the indicator: from a maximum of $109.1 \%$ recorded in $2003 / 2004$ the year of implementation of the measure by which has lowered the school beginning age at 6 years) to a minimum of $97,8 \%$ in $2007 / 2008$ ( 6 pp less compared with the previous school year).

This reduction in the enrollment rate in primary education is, among others, a consequence of the progressive reduction in the number of children aged 6 years in First Class.
In secondary education, the enrollment rate keeps an upward trend since 2002/2003, reaching a maximum of $100.5 \%$ in the year $2007 / 2008$. This increase of almost 4 p.p. compared to the previous school year is, among other things, the consequence of the fact that two cohorts of children ( 6 and 7 years) entered the primary education in the school year 2003/2004. Thus, they entered the secondary education in $2007 / 2008$. (EDU, 2008)

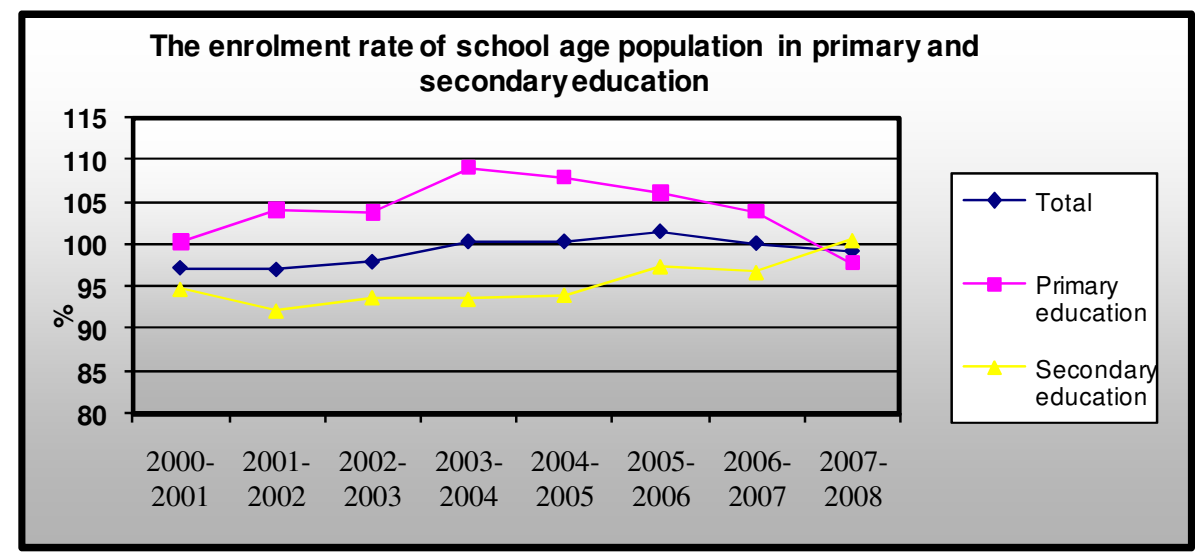

Fig.3. The enrolment rate of school age population in primary and secondary education

\section{B. The average period of attendance the primary and secondary education}

The average period of attendance the primary and secondary education in the school year $2007 / 2008$ is identical to that of the previous year - 7.5 years. Are also, maintained differences between urban and rural population to the detriment of school age population from rural areas. In the school year 2007/2008 this difference was 1 year. (EDU, 2008)

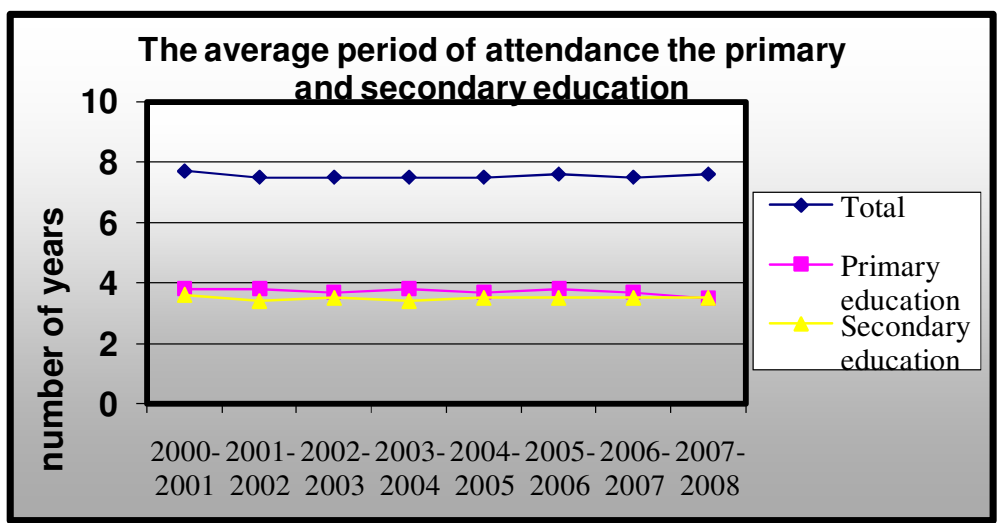

Fig.4. The average period of attendance the primary and secondary 


\section{$C$. The rate of early school leaving \& $D$. The schools drop out}

The rate of early school leaving is the proportion of population aged 18-24 years with secondary education or who has not completed secondary education and who does not follow any form of education and training, out of the total population aged 18-24 years. (EDU, 2008)

The rate of early school leaving in 2007 decreased by 3 pp compared to 2000 . Nevertheless, the perspective to achieve the target set by the EU- reducing the value of this indicator to a maximum of $10 \%$ by 2010 - is still problematic if we take into account the upward trends in the early school leaving in primary and secondary cycle.

The school dropout rate is the difference between the number of pupils enrolled at the beginning of the school year and all those recorded at the end of the same school year, expressed as the percentage in the number of pupils enrolled at the beginning of the school year.

During 2000-2007, the school dropout rate (calculated based on the " entry - exit " method), both over the primary and secondary education and at each of the two cycles, has a continuous upward trend.

The schools drop out is just one component of the losses (repeat, migration, etc.) recorded by the Romanian education system. Thus, during the 2000-2007 school losses recorded for each cohort of school children entering a level of education until the graduation of this level represented approximately $10-15 \%$, which represents over $25 \%$ during primary and secondary education. (EDU, 2008)

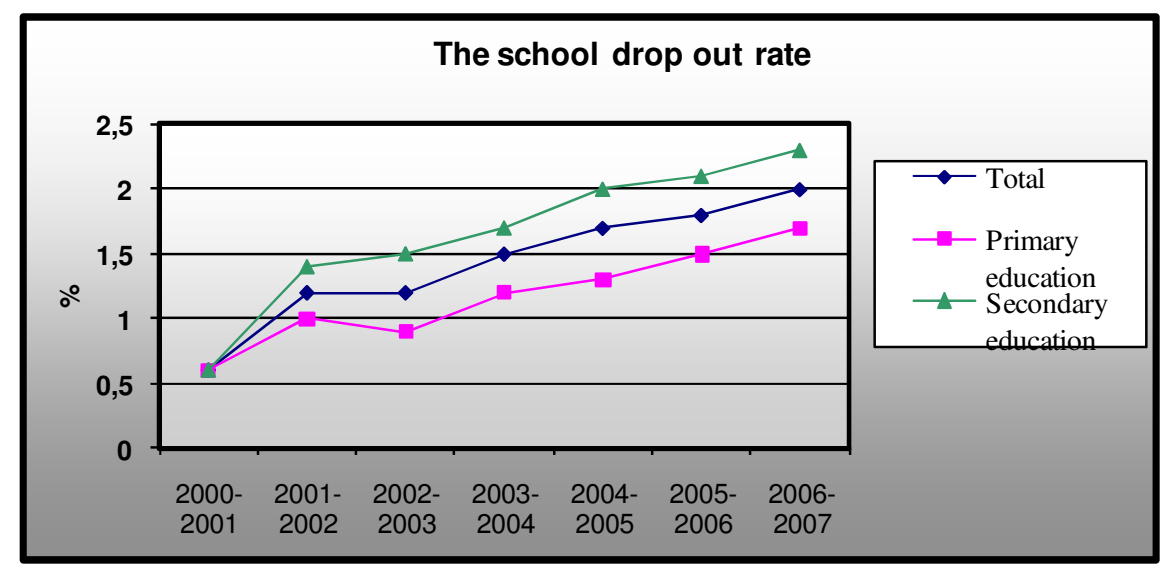

Fig. 5. The school dropout rate in primary and secondary education

\subsection{High-school and vocational education}

\section{A. The enrolment rate of school age population in high-school and vocational education}

Although in constant decline in the reference period of the report, in the school year 2007/2008, the enrollment rate in high-school and vocational education kept the upward trend recorded in the previous year, reaching the value of almost $85 \%$.
Also, almost one third of young people with appropriate school age from rural areas (compared to almost 4\% in urban) does not accesses the secondary level of education, which draws attention to the risk on human capital development in rural areas. 


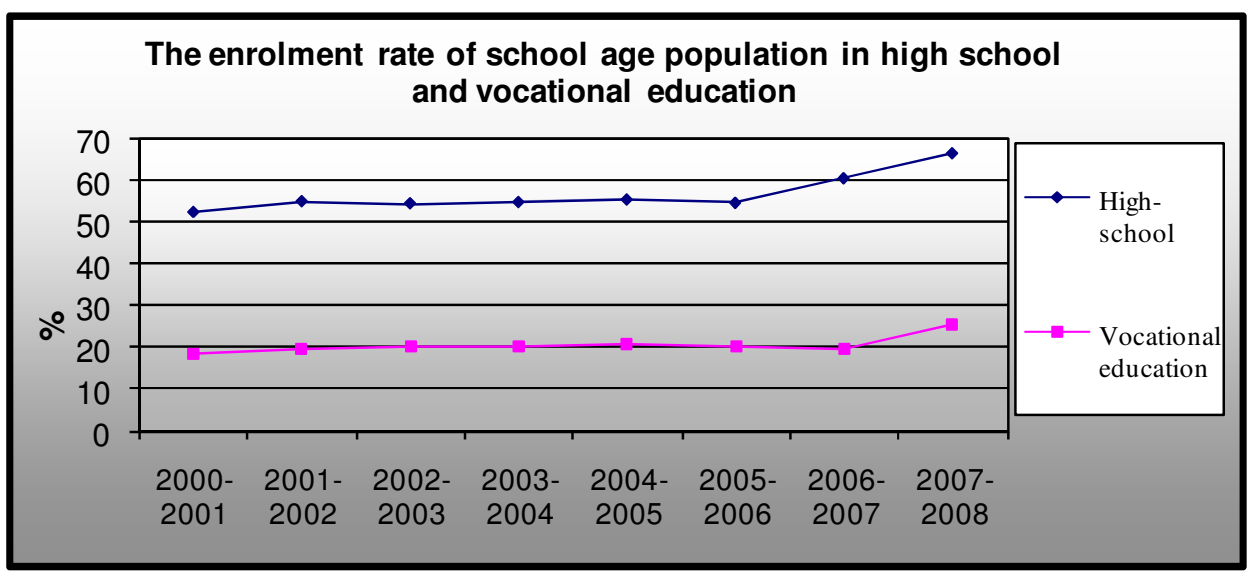

Fig. 6. The enrolment rate of school age population in high school and vocational education

\section{B. The average period of attendance the high-school and vocational education}

The average period of attendance the highschool and vocational education in the school year 2007/2008 was for the highschool education 2 years and for the vocational education 0,7 years. These durations were relatively constant during the reference period.

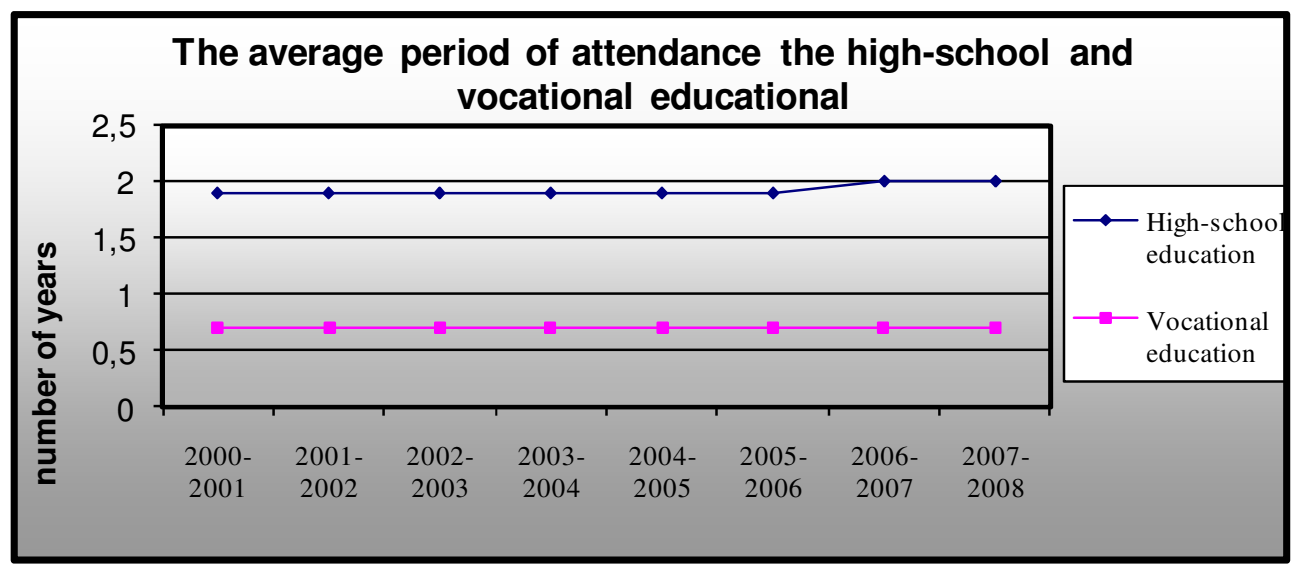

Fig.7. The average period of attendance the high school and vocational education

\section{The rate of transition in high-school/vocational education}

According to the same Report (EDU, 2008) in the reference period, the indicator recorded an oscillating trend. Thus, in 20002004, the rate of transition in high school and vocational education has registered an upward trend: from $89.7 \%$ in the school year $2000 / 2001$ to $92.5 \%$ in $2004 / 2005$.
But, over the next two school years (2005/2006 and 2006/2007) there was a decrease in the indicator value (by about two percentage points), so that in $2007 / 2008$ to achieve the highest value during the interval: $95.2 \%$. 


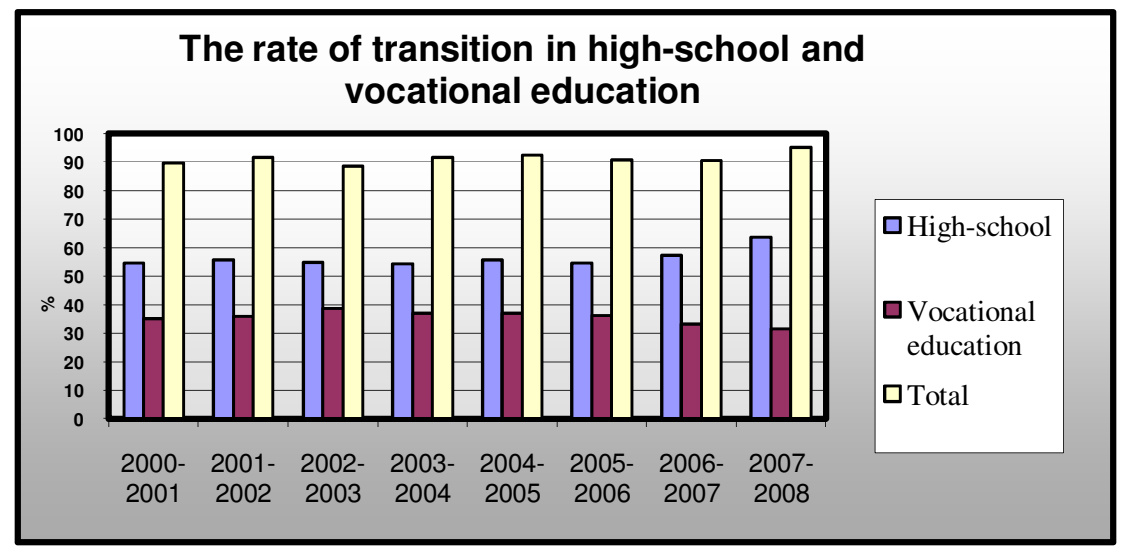

Fig.8. The rate of transition in high-school and vocational education

\section{The school dropout rate}

After a continuous downward trend, the school dropout rate increased in the school years 2005/2006 and 2006/2007, both in high-school and vocational education. High dropout rate registered in vocational education $(8.2 \%)$ involve a significant impact on the internal effectiveness of this segment of the educational system.

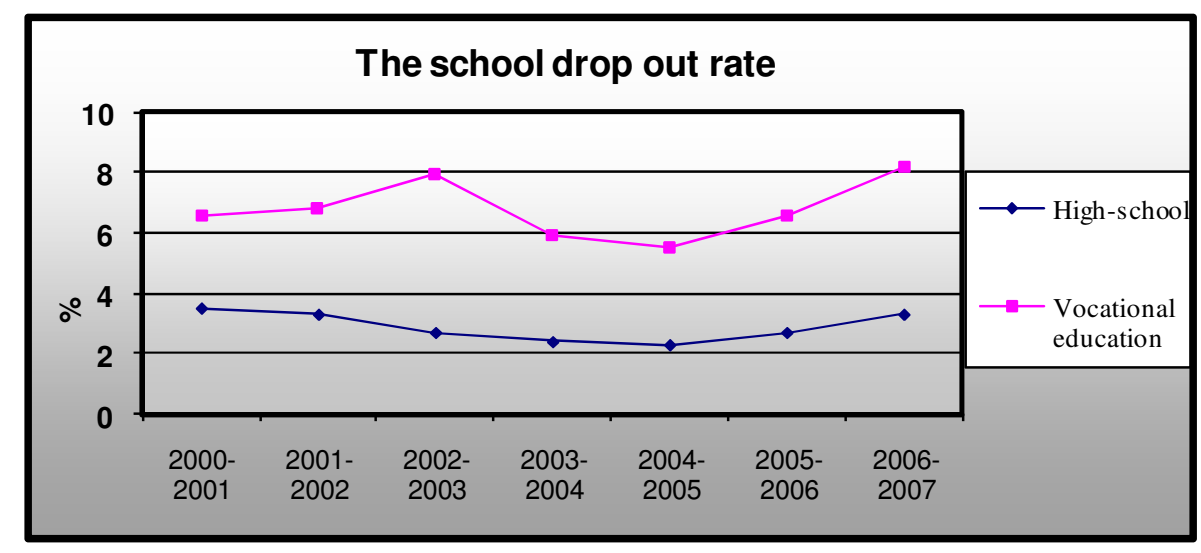

Fig. 9. The school dropout rate in high-school and vocational education

\subsection{Post high-school education, non-tertiary/tertiary education}

\section{A. The enrolment rate of school age population in post secondary education, non- tertiary/tertiary}

In $2007 / 2008$ compared with the previous school year the enrolment rate of school age population registered a slight increase in post high-school education and foreman education. At the higher education level has emphasized the upward trend reaching for the first time over 50\%. The important increase is determined primarily by the growing of the number of students included in private higher education. (EDU, 2008) 


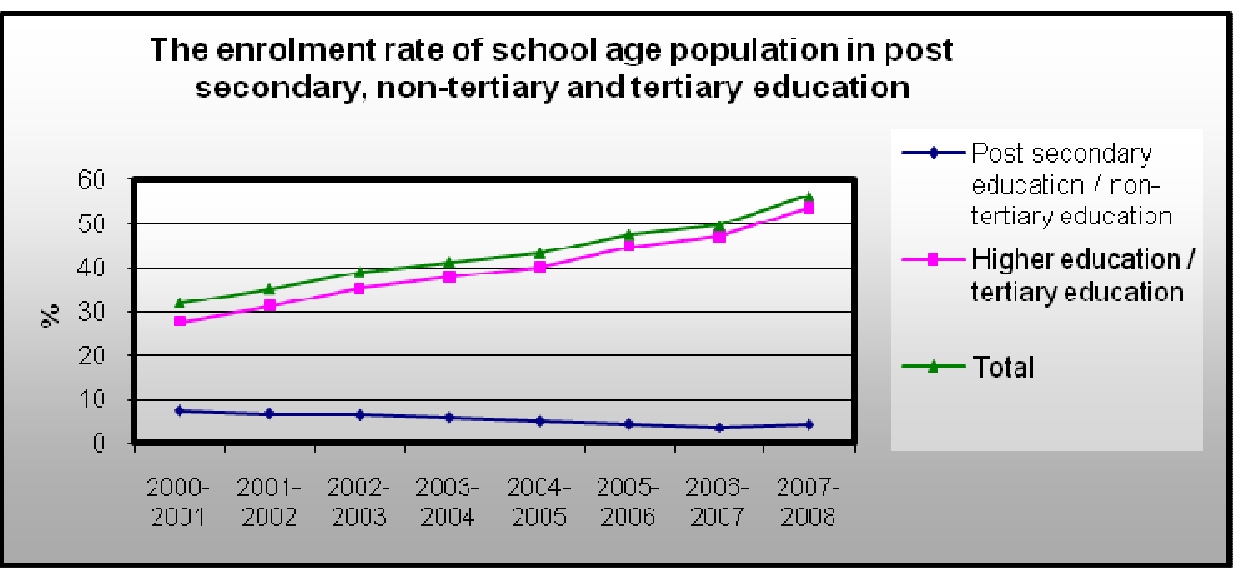

Fig. 10. The enrolment rate of school age population in post secondary, non-tertiary and tertiary education

\section{B. Share of students enrolled in mathematics, science and technology}

The analysis of data provided by EUROSTAT (2009) shows that the share of students enrolled in mathematics, science and technology has recorded in the period 2002-
2007 an oscillating trend. Until 2005 the indicator was above the EU average but starting 2006 its value has fallen below the EU average.

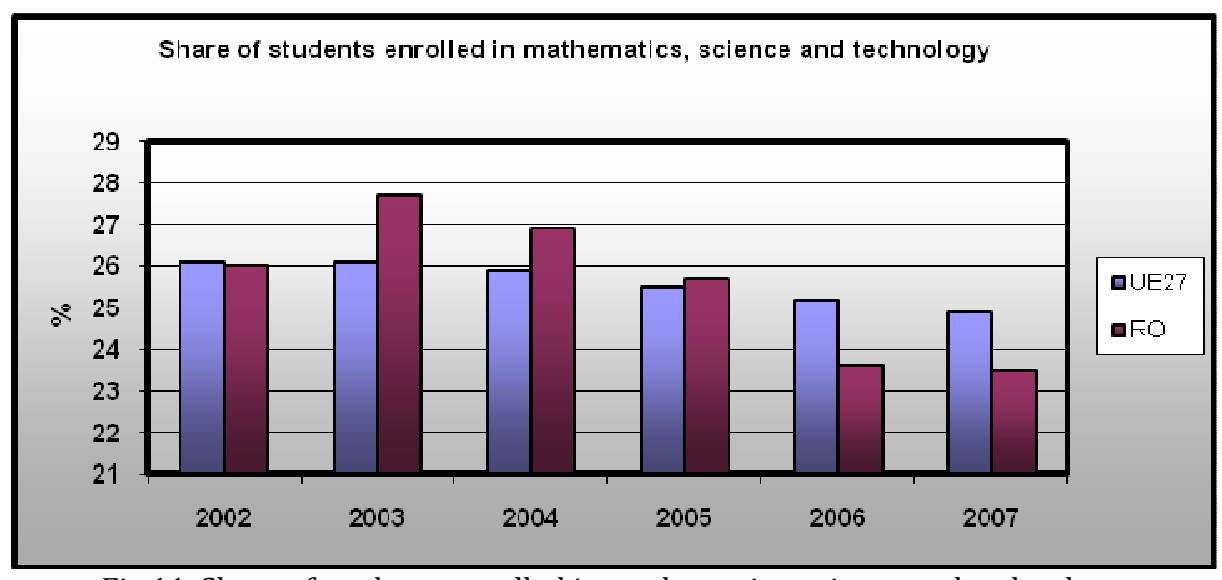

Fig.11. Share of students enrolled in mathematics, science and technology

\section{The rate of transition to higher education and the rate of access to higher education}

The rate of transition to higher education expresses the number of students admitted in the first year of study of higher education in a given school year, as the percentage in the number of pupils enrolled in the terminal year of secondary education from previous school year. The rate of access (of the graduates with the baccalaureate exam from the current series) was calculated by reporting the number of students enrolled in the first year (for the first time) in the number of graduates of the baccalaureate exam from the current series.

During 2000-2007, the rate of transition from secondary education to higher education and the rate of access have been recorded, overall, a continuous upward trend. In the academic year 2007/2008, the two indicators have increased by over 10 percentage points. (EDU, 2008) 


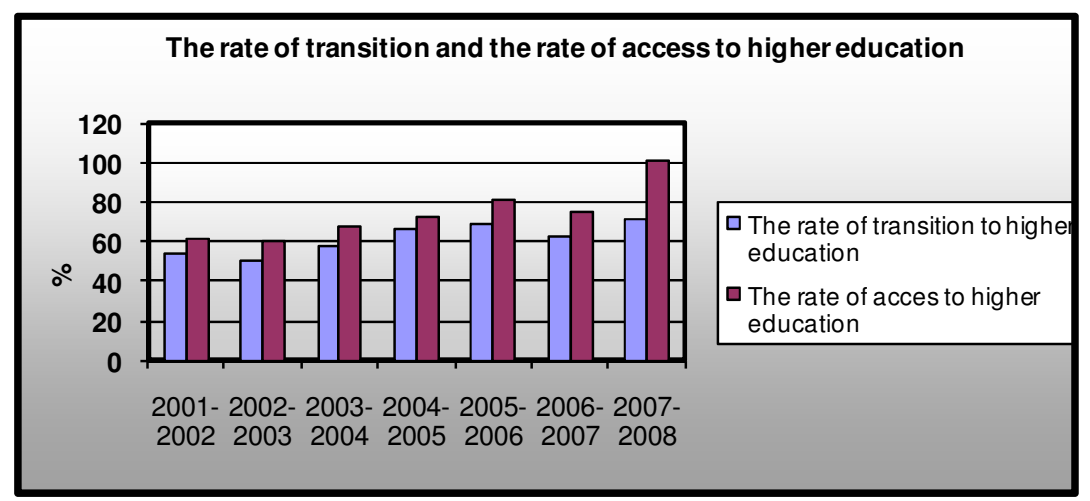

Fig.12. The rate of transition and the rate of access to higher education

\section{The access to the information \& communications technologies (ICTs)}

\begin{abstract}
Information and communications technologies (ICTs) are the backbone of the knowledge economy and in recent years have been recognized as an effective tool for promoting economic growth and sustainable development. With relatively low usage costs and the ability to overcome distance, ICTs have revolutionized the transfer of information and knowledge around the world.
\end{abstract}

ICT infrastructure in an economy refers to the accessibility, reliability and efficiency of computers, phones, television and radio sets, and the various networks that link them. The World Bank Group defines ICTs to consist of hardware, software, networks, and media for collection, storage, processing transmission, and presentation of information in the form of voice, data, text, and images. They range from the telephone, radio and television to the Internet (World Bank, 2003a). On the other hand, the OECD defines ICT sectors as a combination of manufacturing and service industries that capture transmit and display data and information electronically.

In the following I will stop at 3 of the indicators used to measure the accessibility of the population of Romania to ICTs: the endowment of households with computers, the Internet access and the access to networks of fixed and mobile phones. The data presented are provided by the National
Institute of Statistics and Economic Studies and the National Authority for Administration and Regulation in Communications

\subsection{The endowment of households with computer}

The National Institute of Statistics and Economic Studies (NISES)' report “The access of population to information and communications technology" (NISES 2, 2008) states that in 2008 out of the total households from Romania, more than one third had a computer at home (35.0\%), that represents a higher proportion than in 2007 (31.4\%). Among households that own computers at home, four of five are living in urban areas. Compared to the previous year, in 2008 the share of households that have computers at home has increased in both urban (from $46.0 \%$ to $49.4 \%$ ) and rural areas (from $11.9 \%$ to $16.1 \%$ ).

The computer is a sine qua non condition in the contemporary information society, being in the same time the main provider for improvements of performance of pupils / students, and the gateway to the Internet. Also, the report "Population access to information and communications technology" (2008) shows that a high interest in owning a computer was noted in the households headed by employers, nearly four out of five of them having a PC and in the households headed by employees, nearly 3 out of 5 owning computers (59.0\%). 


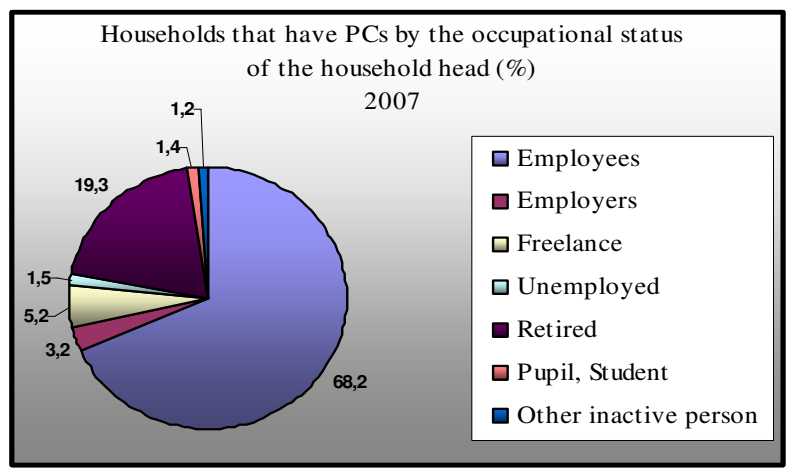

Fig. 13. Households that have PCs by the occupational status of the household head - 2007

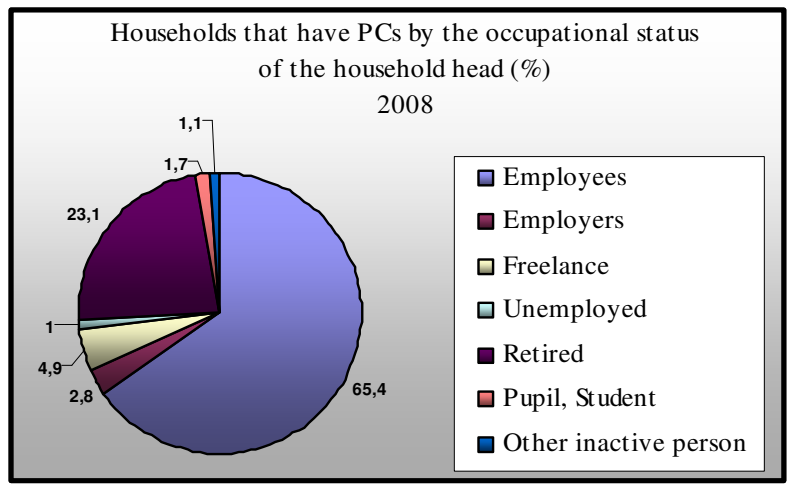

Fig. 14. Households that have PCs by the occupational status of the household head- 2008

The PC is a very useful tool in developing skills for learning and extending the level of training. The endowment of households with computers is as higher as the level of household head education is higher. Thus, if among the households headed by people with higher level of education (post secondary and tertiary education) the most of them have computers, among households whose head have a lower level of education (vocational, primary or secondary education), the shares of households that have computers are modest. (NISES 2, 2008)

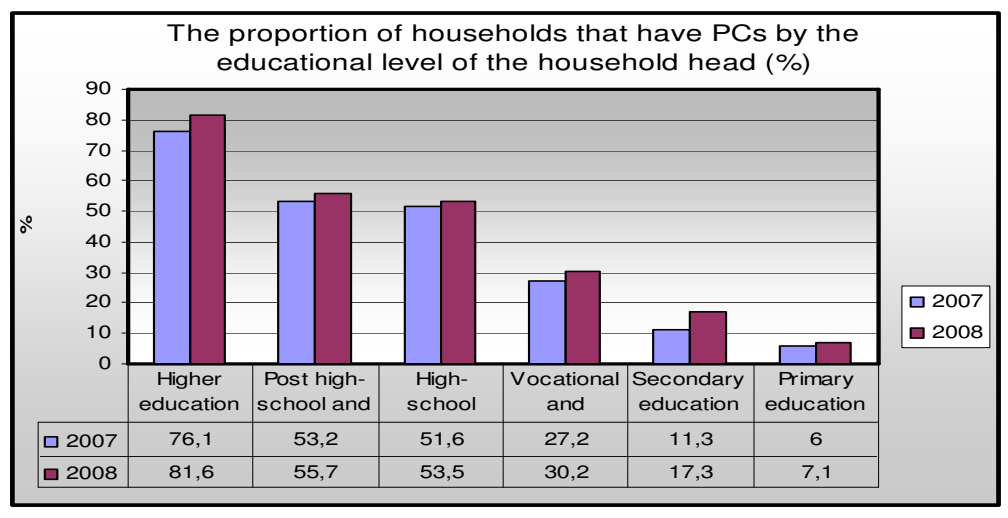

Fig. 15.The proportion of households that have PCs by the educational level of the household head 


\subsection{Internet access}

More than one quarter (27.3\%) of households in Romania has access to the Internet at home, the overwhelming majority ( $88.1 \%$ of them) focusing on urban areas. Compared with 2007, in 2008 the share of households with Internet access has increased by total (from 20.5\% in 2007) in rural areas being almost three times bigger (from $3 \%$ to $8 \%$ ).

The interest in getting connected to the Internet can be put on the opportunities offered in the territory by the providers and the financial resources that have a household. These are the two main reasons that can explain the large gaps between urban and rural area in term of decision to purchase a home computer or for connecting to the Internet network.

Nowadays, the Internet is a portal to a whole universe of knowledge, providing multiple options, both in general and the more detailed areas, proposing a base of information that helps humanity throughout time, while ensuring the possibility of online users' interaction.

As increase the level of training of the head of the household, increase the interest in exploiting this means of knowledge.

Thus, if out of the total of the households headed by people with university level training three quarters are connected to the Internet, and among those led by people who have completed high-school and vocational education about two of five have this kind of information technology, among households whose head of household attained only secondary education level, one of ten is connected to the Internet. Per total almost three quarters of households don't have Internet access at home. (NISES 2, 2008)

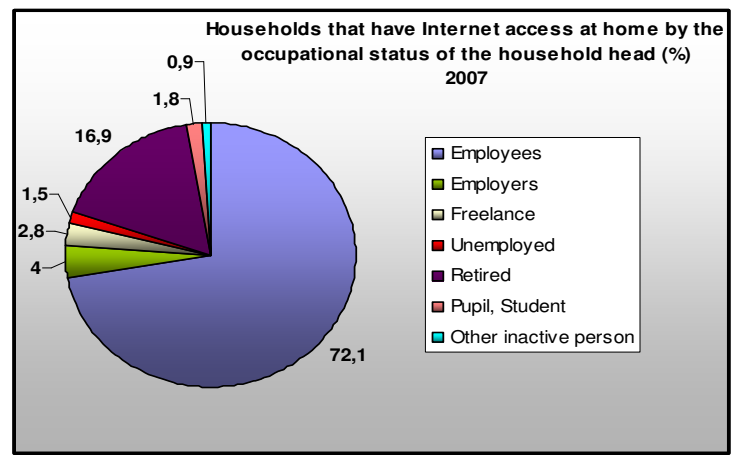

Fig. 16. Households that have internet access at home by the occupational status of the household head - 2007

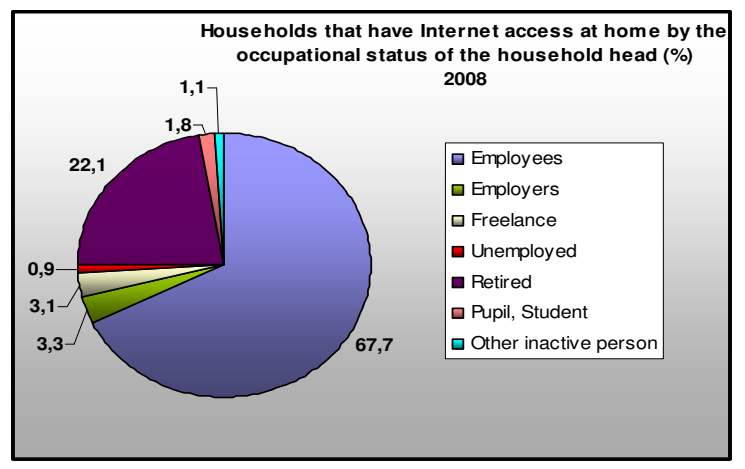

Fig. 17. Households that have internet access at home by the occupational status of the household head - 2008 


\subsection{Access to networks of fixed and mobile}

According to the European Commission's Progress Report on the Single European Electronic Communications Market 2008 (14th Report) mobile phone services grew significantly in 2008 and the typical monthly mobile phone bill was almost $€ 4$ less than in 2007. With a penetration at $103 \%$ of population in January 2009 , there is now more than one mobile phone line per person.

A new development is that customers can now keep their numbers when changing operators. 112, the European emergency number also works better. However, the independence of the national telecoms regulator has been undermined by the Government and there are delays in ensuring that basic telecoms services such as phone directories are accessible to everyone. Take up of broadband internet is among Europe's most sluggish. A comprehensive strategy and further investment would be necessary to improve broadband penetration $(11.7 \%$ in January 2009).

The two largest mobile operators hold $76 \%$ of the market, and the third increased its market share by $53 \%$ with more than 5 million subscribers.

The newest entrant launched its services in 2007, announcing 1.2 million subscribers in November 2008. Consumers in Romania also enjoyed a low average price per minute for mobile voice calls: €0.08 per minute compared to an EU average of $€ 0.14$. (European Commission, 2008)

There are 4.41 million fixed telephony lines, of which $31.3 \%$ are provided by the alternative operators. In July 2008, there were 35 alternative fixed operators providing access using their own infrastructure.

Romania is one of the leading Member States in managed VoIP originated calls, which account for $24 \%$ of the traffic in the fixed sector.

The price for most type of calls made from the fixed networks seems to have decreased considerably in 2008. The market share (direct access lines) of the incumbent continued to decrease, reaching $68.70 \%$ in July 2008 (71.30\% in December 2007) while that of the alternative operators increased to $31.30 \%$ (28.70\% in December 2007)16. Based on their wireless networks, by July 2008 two MNOs had launched fixed access solutions ('Home zone' services), which for the moment have captured less than $1 \%$ of the fixed access market, but which could have considerable growth potential since their providers cover $98 \%$ of the population. (European Commission, 2008)

As we can see, the household access to information and communications technology in Romania is still in the stage of development: only one third of households having computers and $27 \%$ of them having Internet access at home. Also, the endowment of households with computers differ greatly by medium of residence as follows: in urban areas one from two households has a computer and two from five households have access to Internet; in rural areas one from six households has a computer and only $8 \%$ have access to Internet.

Out of the total persons $16-74$ years in Romania, $40 \%$ use or have ever used the computer and almost 34\% accesses currently or have ever accessed the Internet. Most people who use the Internet, access it from home or at work. Using electronic mail, finding information about products and services, as well as downloading games, music and movies are the main purposes of using the Internet. Internet commerce is still insufficiently used, about a tenth of users using this feature.

Concluding, we can say that the use of computers and Internet in households in Romania has a great interest and is growing, with a major capacity to expand in the near future. (NISES 2, 2008)

\section{Conclusion}

The education and the access to the ICTs can help Romania to become a powerful competitor in a changing world. 
As the paper has shown, progresses are made in these two area but we are still in the middle of the way. It is very important from this point to look forward and not backward. It is also, very important to sustain these trends and to focus on the most important mean of becoming effective: education.

The paper has intended to present the pillars of the Knowledge Based Society in Romania. These pillars exist and as we have seen they are under construction. The global crisis can stopped this construction or followed it down. Analyzing these trends we'll help us to see the weak points and the strong points of our evolution towards the Knowledge Based Society and to redirect resources for a sustainable development. And, answering at the question from the paper's title: yes, the KBS is a reality for Romania. At least now it is.

I hope the paper will be continued in the next years in order to analyze the place of Romania between the world's KBS and the effect of global crisis on the Knowledge Based Society in general and on the Romanian way towards the KBS in particular. Is a KBS more resistant in front of recession or not?

\section{Some Recommendation for the Romanian Government}

Without the pretension to exhaust the subject I consider necessary summarizing some recommendations addressed to the Romanian Government. Sure, each of these recommendations may be the subject of an independent work, but as it was not the aim of the paper I will only limit to present them very briefly.

\section{Two are plans that the Government must act}

I. Supporting the national economy to be able to provide the necessary financial resources to fund the educational process at that level that can be available and mandatory for all social categories.

The biggest mistake of the governments that have been succeeded at the head of Romania consisted in the directing of financial resources, own or borrowed, to the process of consumption. In fact, chaotic and wasteful consumption have brought the world economy in the situation that is found today. It is strange how the first lesson of economics taught in school, in fact the basic one, "Needs and Resources" is the one that has been constantly ignored not only by the Romanian governments but also by many other governments from countries with a stronger economy than Romania.

Development for Romania of those economic sectors that produce goods and services with a strong national print (such as food industry and tourism) is both out of the crisis solution and the main source of funding the area that can solve a huge proportion of any negative economic or social situation: education.

II. Creating a strategy to increase the quality of educational system, which involves three stages:

\section{A. Developing a strategic vision.}

This involves first answering the following questions:

a. Who are we?

b. What do we do?

c. Where are we going?

The dominant role in this stage is played, in the case of Romanian education, by the Ministry of Education Research and Innovation, which is necessary to form an overall view on the direction in which the Romanian educational system evolves.

We believe that the possible answers to these three questions might be:

\section{a. Who are we?}

$\checkmark$ We are a people with a specific Balkan education, influenced by political systems that have been succeeded over time and, also, by the religious orientation;

$\checkmark$ We generate human resources not only for the Romanian economic space.

b. What do we do?

Analysis of the existing Romanian educational system shows a lot of problems related to the efficiency of the educational process. The weak link between school and work demonstrate this affirmation.

c. Where we are going?

To the Knowledge-Based Society with all what this involves: flexibility, efficiency, change, reaction, hope, etc.

\section{B. Setting goals}


Nicolae (2004) mentioned that these objectives can be grouped into two main categories:

\section{B1 Financial Goals:}

- Obtaining the necessary amounts to develop optimally the educational process, whether these are taken from public or private sources.

- Achieving a higher rate of return of education, comparable with other EU countries.

\section{B2 Educational Goals:}

- Transformation of the education system in the main generator of competitive human resources in different areas;

- Ensuring flexibility in thinking of graduates;

- International recognition of diplomas;

- Create a close link with the labor market;

- Providing a performance -oriented management, linking individual performance to overall objectives of the organization;

- Enhance training and performance as an essential component of strategic human resource management, etc. (Nicolae, 2004)

\section{Establishment of the strategies}

Even if the establishment of a national educational strategy is the responsibility of the Ministry of Education, Research and Innovation, this does not avoid its subordinated hierarchical levels.

\section{C1. National Strategy}

\section{Financial Strategy}

- Obtaining the necessary amounts through private - public partnership. For example, the involvements of firms in financing research contracts could also bring closer the education to the labor market. But for that to happen it is necessary that the state grant certain tax exemptions to the companies involved in supporting education. Also, paying teachers at a decent level and ensuring the material basis able to sustain a normal educational process are important factors for raising the quality of education in Romania.

- Possibility of lower hierarchical levels to use the amounts allocated from the budget in a timeframe set by them.

\section{Educational Strategy}

- The establishment of the education programs that do not lead to an overload of the student, in this way being a balance between the learning times spent at home and the time spent at school.

- Changing the evaluation system of the students.

- Promoting education for private life.

- Creating analysis of labor market developments and communicating their results at territorial and local level.

- Create a philosophy of Romanian education centered on beneficiary.

- Creating a system of tests for teachers centered not only on professional competence but also on teaching skills, mobility of thought and style of teaching.

\section{C2. Regional Strategy}

The Regional Strategy should primarily aim the link between education and specific of regional labor market, both in the present and in perspective. Each inspectorate should have at least one employee to deal with this issue and should communicate the results of his studies to each educational institution. Sure, this information must be objective and at appropriate level of understanding of their receptor. Also, it should not create the image of a dependency of the students by the space they live in, but neither the idea that their chances of professional fulfillment in their native place are null. (Nicolae, 2004)

\section{C3. Local Strategy}

Financial Strategy

- should focus on attracting additional sources of financing

Educational Strategy:

- Developing educational programs aimed on the mobility of the student thinking, extra-school life and on his involvement in taking decisions.

- It is very important to encourage and, where appropriate, to form a competitive spirit, which includes an open and objective attitude in front of all sort of changes. This is a difficult process because it implies changes not only in the mentality of human resources employed in the educational system but also in the mentality of the entire adult population that was used in the centralized economy with a life-time job and a certain stability.

The following scheme synthesizes the recommendations mentioned above: 


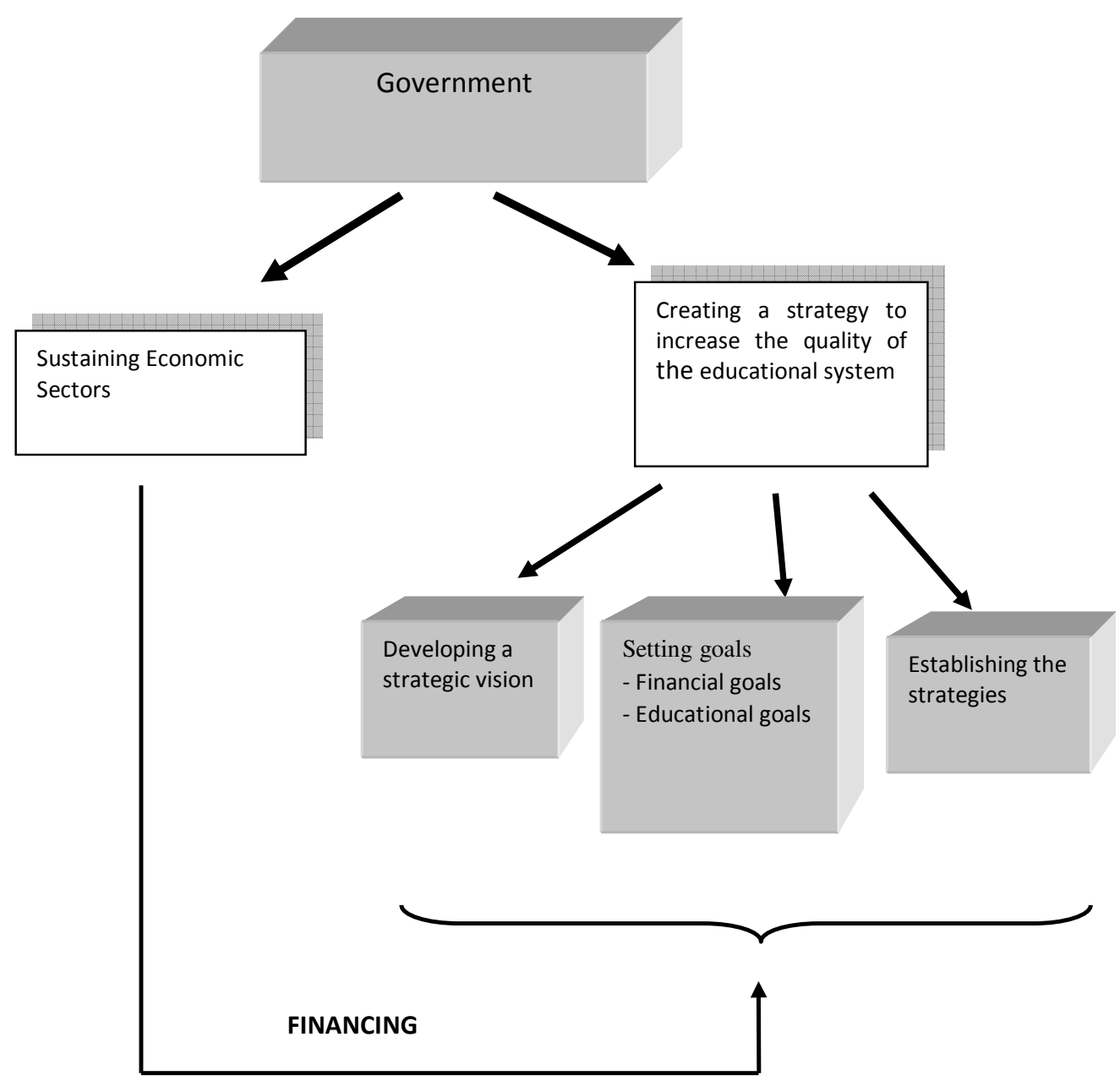


References

ANCOM (2008), "Electronic
communications market in Romania",
2008, p.43, www.ancom.org.ro, [Retrieved
June 30, 2009]

Chen, Derek H.C. and Dahlman, Carl J. (2004), "Knowledge and Development: A Cross-Section Approach" (November 2004), Working Paper No. 3366. World Bank Policy Research Available at SSRN: http://ssrn.com/abstract $=616107$

[Retrieved July 10, 2009]

EDU (2008) - Raport asupra starii sistemului national de invatamant, 2008 (Report on the national state system of education, 2008), http://www.edu.ro, [Retrieved July 5, 2009]

EUROSTAT

(2009)

http://nui.epp.eurostat.ec.europa.eu/nui/s etupModifyTableLayout.do, [Retrieved August 1, 2009]

European Commission, (2008), Romania "Progress Report on the Single European Electronic Communications Market 2008" (14th Report), Available at:

http://ec.europa.eu/information_society/d oc/factsheets/14thimplementation/14thprogress-report-ro-final.pdf, [Retrieved July 25, 2009]

NISES 1 (2008) - „Proiectarea populatiei Romaniei in profil teritorial, la orizontul anului 2050" (Romania's population territorial projection at the horizon year 2050), NISES, Editura „Revista Romana de Statistica", 2008, p 19-20

NISES 2, (2008) - „Accesul populatiei la tehnologia informatiilor si comunicatiilor" (The Access of Population to information and communications technology), NISES, Editura „Revista Romana de Statistica”, 2008, p 31

Nicolae, S. (2004), "Pregatirea profesionala in Romania. Working Society versus Learning Society", Editura PRINTECH, Bucharest, 2004, p. 80, ISBN 973-718-0216

World Bank (2003a), "Engendering ICT: Ensuring Gender Equality in ICT for
Development", Washington, D.C., September. 